\title{
Initial performance of maize in response to humic acids and plant growth-promoting bacteria ${ }^{1}$
}

\author{
Raphael Oliveira de Melo ${ }^{2}$, Hend Pereira de Oliveira ${ }^{3}$, Klever Cristiano Silveira ${ }^{3}$, \\ Lílian Estrela Borges Baldotto ${ }^{3 *}$, Marihus Altoé Baldotto ${ }^{3}$
}

10.1590/0034-737X201865030007

\begin{abstract}
Seed treatment with inoculants based on plant growth-promoting bacteria (PGPB) or the application of humic acids (HA) may increase the productivity of plants of agricultural interest. The hypothesis of this work is that it is possible to combine the effect of plant growth promoting characteristic of HA with the inoculation of PGPB selected strains in the treatment of maize seeds. Thus, providing superior responses than in single applications of both in the initial maize development. To meet this purpose, we conducted isolated application of HA or PGPB inoculation of Burkholderia gladioli and Rhizobium cellulosilyticum, and the combined application of PGPB and HA for treatment of maize seeds. At the end of the experiment (45 days after germination), the plants were evaluated biometrically, nutritionally and a bacteria count was performed in plants using the Most Probable Number technique. The results showed that it is possible to combine the effects of HA with the inoculation of selected strains of PGPB, obtaining superior responses to the isolated application of both. Thus, the use of HA-based bio-stimulants in combination with PGPB is positive and complementary compared to inputs generally used in the treatment of maize seeds.
\end{abstract}

Keywords: humic substances; diazotrophic bacteria; soil organic matter.

\section{RESUMO}

\section{Desempenho inicial do milho em resposta a ácidos húmicos e bactérias promotoras de crescimento vegetal}

O tratamento de sementes com inoculantes a base de bactérias promotoras de crescimento de vegetal (BPCV) ou a aplicação de ácidos húmicos $(\mathrm{AH})$ podem aumentar a produtividade de plantas de interesse agrícola. A hipótese deste trabalho propõe que é possível combinar o efeito de promoção do crescimento vegetal característico dos AH com a inoculação de estirpes selecionadas de BPCV no tratamento de sementes de milho com vias a obtenção de respostas superiores à aplicação isolada de ambos no desenvolvimento inicial do milho. Para atender esse propósito foi feita a aplicação isolada de AH ou a inoculação de BPCV das espirpes Burkholderia gladioli e Rhizobium cellulosilyticum, e o uso conjunto de BPCV e AH através do tratamento de sementes de milho. Ao final do experimento (45 dias após a germinação), as plantas foram avaliadas biometricamente, nutricionalmente e foi realizada a contagem de bactérias nas plantas pela técnica do Número Mais Provável. Os resultados demonstraram ser possível combinar os efeitos dos AH com a inoculação de estirpes selecionadas de BPCV com vias a obtenção de respostas superiores à aplicação isolada de ambos. Assim o uso de bioestimulantes à base de AH, em combinação com BPCV é positivo e complementar comparativamente aos insumos geralmente usados no tratamento de sementes de milho.

Palavras-chave: substâncias húmicas; bactérias diazotróficas; matéria orgânica do solo.

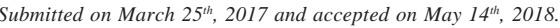

' Project funded by FAPEMIG.

${ }^{2}$ Universidade Federal de Viçosa, Departamento de Fitotecnia, Viçosa, Minas Gerais, Brazil. raphael.o.melo@ufv.br

3Universidade Federal de Viçosa, Instituto de Ciências Agrárias, Florestal, Minas Gerais, Brazil. hend.oliveira@ufv.br; klever.silveira@ufv.br; lilian.estrela@ufv.br; marihus@ufv.br 'Corresponding author: liestrelaborges@gmail.com; lilian.estrela@ufv.br
} 


\section{INTRODUCTION}

In the search for higher current levels of productivity and reduction in maize production costs, new technologies have been incorporated into the production systems, among them, the use of biostimulants and inoculants based on plant growth-promoting bacteria (PGPB). These agronomic strategies are considered promising for productivity increase and have gained space and importance in recent years (Alves et al., 2014).

Plant growth-promoting bacteria can stimulate plant growth and development through physiological and biochemical stimuli as a function of the production of organic acids, phytohormones and enzymes (Ahemad \& Kibret, 2014), improving the absorption of water and nutrients (Günes et al., 2014) and fixing atmospheric nitrogen (Montañez et al., 2009). Several PGPB genera are being studied because of their ability to establish associations with economically attractive grasses, such as sorghum, rice, sugarcane and wheat (Idris et al., 2009; Pedrosa et al., 2011; Majeed et al., 2015). For maize, the results of plant growth promotion with PGPB inoculation of the genera Herbaspirillum and Azospirillium, are well documented, being the latter with registration in the Ministry of Livestock Farming and Supply for use in commercial formulations (Hungria et al., 2010). Recently, there has been great interest in studies of other genera for formulations of inoculants among these Rhizobium and Burkholderia (Qureshi et al., 2013; Perin et al., 2006).

Historically, the promotion of plant growth in plants of commercial interest in association with the genus Rhizobium are restrict to the leguminous group (Masson-Boivin et al., 2009). However, recent studies point out that bacteria of this genus are endophytes of non-leguminous plants, among them maize, and many have shown the beneficial effect on plant growth (Qureshi et al., 2013; García-Fraile et al., 2012). In the same way, PGPB of Burkholderia have a distribution in the Poaceae family with species associated to maize capable to promote plant growth (Perin et al., 2006; Estrada de Los Santos et al., 2001).

There is a current research challenge of identifying management conditions that may contribute to the optimization of PGPB effects in host plants. In this way these bacteria can have their action potentiated with combined inoculation with other biostimulant sources, such as humic acids (HA), which are complexes that promote hormonal balance of plants, favoring the expression of plant metabolism, increasing the use efficiency of luminosity, water and nutrients (Baldotto \& Baldotto, 2016; Baldotto et al., 2016; Melo et al., 2015). HA may also increase the establishment of bacterial inoculum inside the plant, through changes in the root system. Specifically, in the architecture of roots and in its growth dynamics, causing increase in density and surface area of roots, as a function of stimuli in the elongation of main and lateral roots. Also, increase in the production of lateral roots and root hair (Baldotto et al., 2011; Silva et al., 2011; Canellas $\&$ Olivares, 2014). The increase of lateral roots and mitotic sites increase the infection points for bacteria, Marques Júnior et al. (2008) states that there is great potential for the joint use of HA and PGPB bacteria. Canellas et al. (2012) demonstrated that the isolated application of humic acids or the inoculation of diazotrophic bacteria of the genus Herbaspirillum, as well as their combined use, showed a biostimulating effect of plant growth on maize seedlings. The benefits of the use of combined HA and PGPB inoculants, besides already being reported in maize, have been reported in other crops of agricultural interest: sugarcane (Marques Júnior et al., 2008), pineapple (Baldotto et al., 2010), and tomato (Olivares et al., 2015).

Nevertheless, due to the complex and still little known nature of HA, the study of the effects of these substances on inoculant composition is encouraged, since the behavior may be different among the different genera or PGPB strains. Matsumura et al. (2015) states that inoculation response may vary depending on strain or bacterial genera, plant genotype, environmental conditions, agricultural practices, as well as the quantity and quality of PGPB cells used as an inoculant. Thus, the objective of this work was to evaluate the initial development of maize in response of HA and PGPB of the Burkholderia gladioli and Rhizobium cellulosilyticum strains aiming to understand the effects of this combination.

\section{MATERIAL AND METHODS}

The experiment was conducted at the Florestal Campus of the Universidade Federal de Viçosa (CAF-UFV), located at coordinates of $19^{\circ} 52^{\prime} 16.3^{\prime \prime} \mathrm{S}$ and $44^{\circ} 25^{\prime} 26.1^{\prime \prime} \mathrm{W}$, at an altitude of approximately 750 meters, in the first semester of 2015 .

The experiment was based on the isolated application of humic acids or the inoculation of diazotrophic bacteria of the species Burkholderia gladioli and Rhizobium cellulosilyticum, as well as their combined use with humic acids in maize seed treatment. Six treatments were used: 1Control (T1); 2- Humic Acids (HA) (T2); 3-Burkholderia (T3); 4-Burkholderia + HA (T4); 5- Rhizobium (T5); 6Rhizobium + HA (T6). The experiment was carried out in a completely randomized design, consisting of four replications totaling 24 experimental units.

Humic acids were isolated from organic compounds obtained from bovine manure characterized by (Baldotto et al., 2016) from the CAF-UFV stable whose zootechnical management follows the recommendations of Embrapa (2001) for organic residues from bovine animals. 
For the preparation of the inoculum, the bacteria Burkholderia gladioli and Rhizobium cellulosilyticum were selected. A colony of each strain was inoculated into $5 \mathrm{~mL}$ of liquid DYGS medium (Rodrigues Neto et al., 1986) and remained under agitation at $150 \mathrm{rpm}$ for $24 \mathrm{~h}$ at $30^{\circ} \mathrm{C}$. An aliquot of $30 \mu \mathrm{L}$ of the culture grown was transferred to glass vials ( $12 \mathrm{~mL}$ volume) containing $5 \mathrm{~mL}$ of the culture medium corresponding to the bacteria used in its isolation, which was the JMV and JNFb semi-solid medium for Burkholderia gladioli and Rhizobium cellulosilyticum, respectively. The flasks were incubated for bacterial growth for $72 \mathrm{~h}$ at $30^{\circ} \mathrm{C}$.

The maize seeds (Zea mays L.) variety AG1051, were submerged in their respective solutions of the treatments, with humic acids at $23 \mathrm{mmol} \mathrm{L}^{-1}$ of $\mathrm{C}$ of $\mathrm{HA}$ isolated from bovine manure for 16 hours (Melo et al., 2015) and for 2 hours in the bacterial solution $\left(131 \times 10^{3} \mathrm{CFU} / \mathrm{mL}\right)$. The control was submerged in water for 18 hours. For this procedure, the seeds were placed in plastic cups containing the amount of solution necessary to leave them submerged. After the seeds were planted in $1 \mathrm{dm}^{3}$ pots, containing soil corrected and fertilized by chemical analysis of the substrate, with usual determinations recommended for the State of Minas Gerais by Ribeiro (1999).

Five seeds were sown per pot, and after emergence of the plants, three were removed and two remained for conducting the experiment. The vessels were irrigated every day. The experimental units remained in the greenhouse for 45 days. At the end of the experiment, the following variables were determined: plant height $(\mathrm{PH})$; Number of leaves (NL); Width of the largest leaf (WLL); Length of largest leaf (LL); Stem diameter (SD). At collection of the experiment, the plants were cut close to the substrate and the fresh matter of the aerial part (FMAP) was determined. Plants' roots were separated from the substrate, washed in running water, to determine their fresh matter (RFM). Both the aerial part and root system were packed in paper bags and kept in a forced air ventilation oven at $60^{\circ} \mathrm{C}$ for 72 hours, sufficient time for the dehydration of plant materials to the constant weight and for determination of their dry matter of the aerial part (DMAP) and root dry matter (RDM). The total dry matter (TDM) was obtained by adding DMAP and RDM. After drying, the maize leaves were milled in a Wiley type mill coupled to $0.25 \mathrm{~mm}$ (60 mesh) sieves. Then, the powder obtained was subjected to sulfur digestion combined with hydrogen peroxide and the total contents of $\mathrm{N}, \mathrm{P}$ and $\mathrm{K}$ were determined. For N, the Kjeldahl method was used; The $\mathrm{P}$ content was obtained by molecular absorption spectrophotometry (colorimetry), after reaction with vitamin $\mathrm{C}$ and ammonium molybdate, at the wavelength of $725 \mathrm{~nm}$; The determination of $\mathrm{K}$ was performed by flame photometry. The data were submitted to analysis of variance and the means of the treatments were compared by Tukey's test, at 5\% probability.

In addition to the biometric analyses, bacterial counting was performed using the Most Probable Number technique (MPN). Samples of $1 \mathrm{~g}$ of leaves and $1 \mathrm{~g}$ of root seedlings were immersed in $9 \mathrm{~mL}$ of saline solution $\left(\mathrm{NaCl}, 8.5 \mathrm{~g} \mathrm{~L}^{-1}\right)$. From these dilutions $\left(10^{-1}\right)$ serial dilutions were performed by taking $1 \mathrm{~mL}$ of the original solution in $9 \mathrm{~mL}$ of the saline solution until dilution $10^{-6}$. Aliquots of $100 \mu \mathrm{L}$ of the different dilutions were transferred in triplicate to glass vials containing $5 \mathrm{~mL}$ of the JMV and JNFb culture media for Burkholderia gladioli and Rhizobium cellulosilyticum, respectively (Döbereiner et al., 1995), all semi-solid and without addition of nitrogen. The formation of a typical aerobic film on the surface of the medium after 7 days of incubation in a growth chamber at $30{ }^{\circ} \mathrm{C}$ was considered positive growth. The results of the growth of diazotrophic bacteria in the semi-solid media were used to calculate the most probable number (MPN) of bacteria according to the McCrady's table for three replicates per dilution. The results obtained in the McCrady's table were submitted to logarithmic transformation, and then the mean and standard error of the mean for each treatment were calculated.

\section{RESULTS AND DISCUSSION}

The results showed that it is possible to combine the effect of plant growth promoting characteristic of humic acids (HA) with the inoculation of selected strains of endophytic diazotrophic bacteria to obtain superior responses to the isolated application of both (Table 1 and 2). Seeds inoculated with Rhizobium cellulosilyticum bacteria did not differ statistically from the control for biometric measurements of dry matter of aerial part and total (Table 1) and phosphorus and potassium contents (Table 2). However, they produced significant effects in relation to control when applied together with humic acids for these characteristics (Table 1 and 2). The observed results can be explained by the effect of HA increasing the population of this strain inside the plant (Figure 1). This favored the uptake and assimilation of nutrients and, phytohormone production guaranteeing a higher relative increase of dry matter, and higher contents of phosphorus and potassium in the plants (Table 1 and 2).

The PGPB infection process occurs from its penetration into plant tissue through small openings created by new lateral roots emergence, and by roots and/or in the rhizosphere ion transport process (Canellas et al., 2012). The positive influence of HA on the PGPB population in the plant (Figure 1) occurs through biostimulation mechanisms in the root system development, through substances analogous to synthetic growth regulators, such as auxins (Trevisan et al., 2010). They can provide 
increased ATPase activity, assisting in root expansion that increases the sites for PGPB colonization in the roots (Marques Júnior et al., 2008). Quaggiotti et al. (2004) demonstrated that humic substances induce Mha2 gene coding, one of the main types of $\mathrm{H}^{+}$-ATPase expressed in cells of maize roots.

Results like this study where HA increased the PGPB population were obtained by Canellas et al. (2012), who observed that the application $\mathrm{HA}$ isolates from vermicomposting at $20 \mathrm{mg}$ of $\mathrm{C} \mathrm{L}^{-1}$ applied through seed treatment, stimulated a greater lateral growth of maize roots favoring a greater colonization inside the plants by Herbaspirillum seropedicae. In a similar way, Conceição et al. (2008) stated that at certain concentrations, humic acids can stimulate the growth of endophytic microorganisms in maize plants.

The PGPBs once associated with a host, stimulate a higher density and length of root hair, as well as the rate of appearance of lateral roots. This increases root contact surface, due to the production of phytohormones such as auxins, cytokinins and gibberellins (Poonguzhali et al., 2008). In addition, PGPBs promote greater release of organic acids (Ahemed \& Kibret, 2014), which potentiates nutrient absorption and water available in the soil, guaranteeing a greater accumulation of biomass. This fact was seen in this work in which there was significant increase in the total dry matter (TDM), and in $\mathrm{P}$ and $\mathrm{K}$ contents with the combined application of humic acids and Rhizobium cellulosilyticum (Table 1 and 2). Similar results were obtained by Qureshi et al. (2013) where the inoculation of maize seeds with different PGPB of the genus Rhizobium increased the fresh and dry matter of plants at the end of 45 experimental days. The increase of TDM observed in the treatment with combined application of humic acids and Rhizobium cellulosilyticum (Table 1) could be reflected in higher crop productivity. Plants with a higher initial growth with accumulation of dry matter increase solar radiation use available at the beginning of the cycle, thus increasing the availability of carbohydrates for better performance (Almeida et al., 2003). This is reinforced by the fact that maize is a type $\mathrm{C} 4$ metabolism, tending to better express its genetic potential due to the greater use of solar radiation. Hence, the higher growth of biostimulated plants results in greater photosynthetic

Table 1: Mean values of biometric characteristics: plant height (PH); Number of leaves (NL); Width of the largest leaf (WLL); Length of largest leaf (LL); Stem diameter (SD); Fresh matter of the aerial part (FMAP); Dry matter aerial part (DMAP); Root fresh matter (RFM); Root dry matter (RDM), Total dry matter (TDM), as a function of the application of humic acids (HA), inoculation of bacteria (BAC), and joint use of humic acids and bacteria (HA+BAC)

\begin{tabular}{lcccccccccc}
\hline Treatments & $\begin{array}{c}\text { PH } \\
\text { cm }\end{array}$ & NL & $\begin{array}{c}\text { WWL } \\
\mathbf{c m}\end{array}$ & $\mathbf{L}$ & $\begin{array}{c}\text { SD } \\
\text { g/plant }\end{array}$ & FMAP & RFM & DMAP & RDM & TDM \\
\hline Control & $27.80 \mathrm{a}$ & $4.60 \mathrm{a}$ & $2.66 \mathrm{a}$ & $55.94 \mathrm{a}$ & $0.47 \mathrm{a}$ & $8.64 \mathrm{a}$ & $6.14 \mathrm{a}$ & $1.05 \mathrm{~b}$ & $0.71 \mathrm{a}$ & $1.75 \mathrm{~b}$ \\
$\mathrm{HA}^{1}$ & $28.20 \mathrm{a}$ & $4.50 \mathrm{a}$ & $2.35 \mathrm{a}$ & $53.40 \mathrm{a}$ & $0.47 \mathrm{a}$ & $8.96 \mathrm{a}$ & $5.70 \mathrm{a}$ & $1.11 \mathrm{~b}$ & $0.61 \mathrm{a}$ & $1.79 \mathrm{~b}$ \\
$\mathrm{Bac}^{2}$ & $31.69 \mathrm{a}$ & $4.86 \mathrm{a}$ & $2.66 \mathrm{a}$ & $59.86 \mathrm{a}$ & $0.56 \mathrm{a}$ & $11.19 \mathrm{a}$ & $5.90 \mathrm{a}$ & $1.36 \mathrm{ab}$ & $0.60 \mathrm{a}$ & $1.99 \mathrm{ab}$ \\
$\mathrm{Bac}^{3}$ & $31.82 \mathrm{a}$ & $4.70 \mathrm{a}$ & $2.71 \mathrm{a}$ & $62.40 \mathrm{a}$ & $0.60 \mathrm{a}$ & $12.98 \mathrm{a}$ & $7.34 \mathrm{a}$ & $1.46 \mathrm{ab}$ & $0.89 \mathrm{a}$ & $2.35 \mathrm{ab}$ \\
$\mathrm{Bac} 1+\mathrm{HA}$ & $30.00 \mathrm{a}$ & $4.86 \mathrm{a}$ & $2.56 \mathrm{a}$ & $56.24 \mathrm{a}$ & $0.57 \mathrm{a}$ & $11.61 \mathrm{a}$ & $6.44 \mathrm{a}$ & $1.39 \mathrm{ab}$ & $0.80 \mathrm{a}$ & $2.19 \mathrm{ab}$ \\
$\mathrm{Bac} 2+\mathrm{HA}$ & $32.00 \mathrm{a}$ & $4.90 \mathrm{a}$ & $2.60 \mathrm{a}$ & $62.70 \mathrm{a}$ & $0.60 \mathrm{a}$ & $13.81 \mathrm{a}$ & $7.54 \mathrm{a}$ & $1.80 \mathrm{a}$ & $0.95 \mathrm{a}$ & $2.75 \mathrm{a}$ \\
\hline $\mathrm{CV}(\%)$ & 10.73 & 7.85 & 11.57 & 8.79 & 11.21 & 22.81 & 15.40 & 21.24 & 19.78 & 19.28 \\
\hline
\end{tabular}

${ }^{1}$ Humic acids isolated from bovine manure $(23 \mathrm{mmol} \mathrm{L}-1$ of $\mathrm{C}) ;{ }^{2}$ Burkholderia gladioli; ${ }^{3}$ Rhizobium cellulosilyticum. Means followed by lower case letters are statistically similar to each other by Tukey test at $5 \%$ probability.

Table 2: Macronutrient levels and amount: nitrogen $(\mathrm{N})$, phosphorus $(\mathrm{P})$ and potassium $(\mathrm{K})$ respectively in maize, in response to application of humic acids (HA), inoculation of bacteria (BAC), and joint use of humic acids and bacteria (HA + BAC)

\begin{tabular}{|c|c|c|c|c|c|c|}
\hline \multirow{3}{*}{ Treatments } & \multicolumn{3}{|c|}{ Content } & \multicolumn{3}{|c|}{ Amount } \\
\hline & $\mathbf{N}$ & $\mathbf{P}$ & $\mathbf{K}$ & $\mathbf{N}$ & $\mathbf{P}$ & $\mathbf{K}$ \\
\hline & \multicolumn{3}{|c|}{$\%$} & \multicolumn{3}{|c|}{ mg per plant } \\
\hline Control & $1.80 \mathrm{a}$ & $0.20 \mathrm{a}$ & $5.56 \mathrm{a}$ & $20.74 \mathrm{a}$ & $2.17 \mathrm{~b}$ & $59.02 \mathrm{~b}$ \\
\hline $\mathrm{HA}^{1}$ & $2.09 \mathrm{a}$ & $0.21 \mathrm{a}$ & $5.57 \mathrm{a}$ & $15.57 \mathrm{a}$ & $2.34 \mathrm{~b}$ & $62.60 \mathrm{~b}$ \\
\hline $\mathrm{Bac} 1^{2}$ & $1.12 \mathrm{a}$ & $0.21 \mathrm{a}$ & $5.91 \mathrm{a}$ & $21.66 \mathrm{a}$ & $2.83 \mathrm{ab}$ & $81.03 \mathrm{ab}$ \\
\hline $\operatorname{Bac} 2^{3}$ & $1.10 \mathrm{a}$ & $0.21 \mathrm{a}$ & $5.54 \mathrm{a}$ & $21.68 \mathrm{a}$ & $3.04 \mathrm{ab}$ & $81.78 \mathrm{ab}$ \\
\hline Bac $1+\mathrm{HA}$ & $1.93 \mathrm{a}$ & $0.19 \mathrm{a}$ & $5.51 \mathrm{a}$ & $14.02 \mathrm{a}$ & $2.83 \mathrm{ab}$ & $76.47 \mathrm{ab}$ \\
\hline $\mathrm{Bac} 2+\mathrm{HA}$ & $0.94 \mathrm{a}$ & $0.21 \mathrm{a}$ & $5.58 \mathrm{a}$ & $14.02 \mathrm{a}$ & $3.72 \mathrm{a}$ & $100.46 \mathrm{a}$ \\
\hline $\mathrm{CV}(\%)$ & 14.70 & 0.96 & 4.97 & 22.76 & 20.92 & 21.15 \\
\hline
\end{tabular}

${ }^{1}$ Humic acids isolated from bovine manure $\left(23 \mathrm{mmol} \mathrm{L}{ }^{-1}\right.$ of $\left.\mathrm{C}\right) ;{ }^{2}$ Burkholderia gladioli; ${ }^{3}$ Rhizobium cellulosilyticum. Means followed by lower case letters are statistically similar to each other by Tukey test at $5 \%$ probability. 


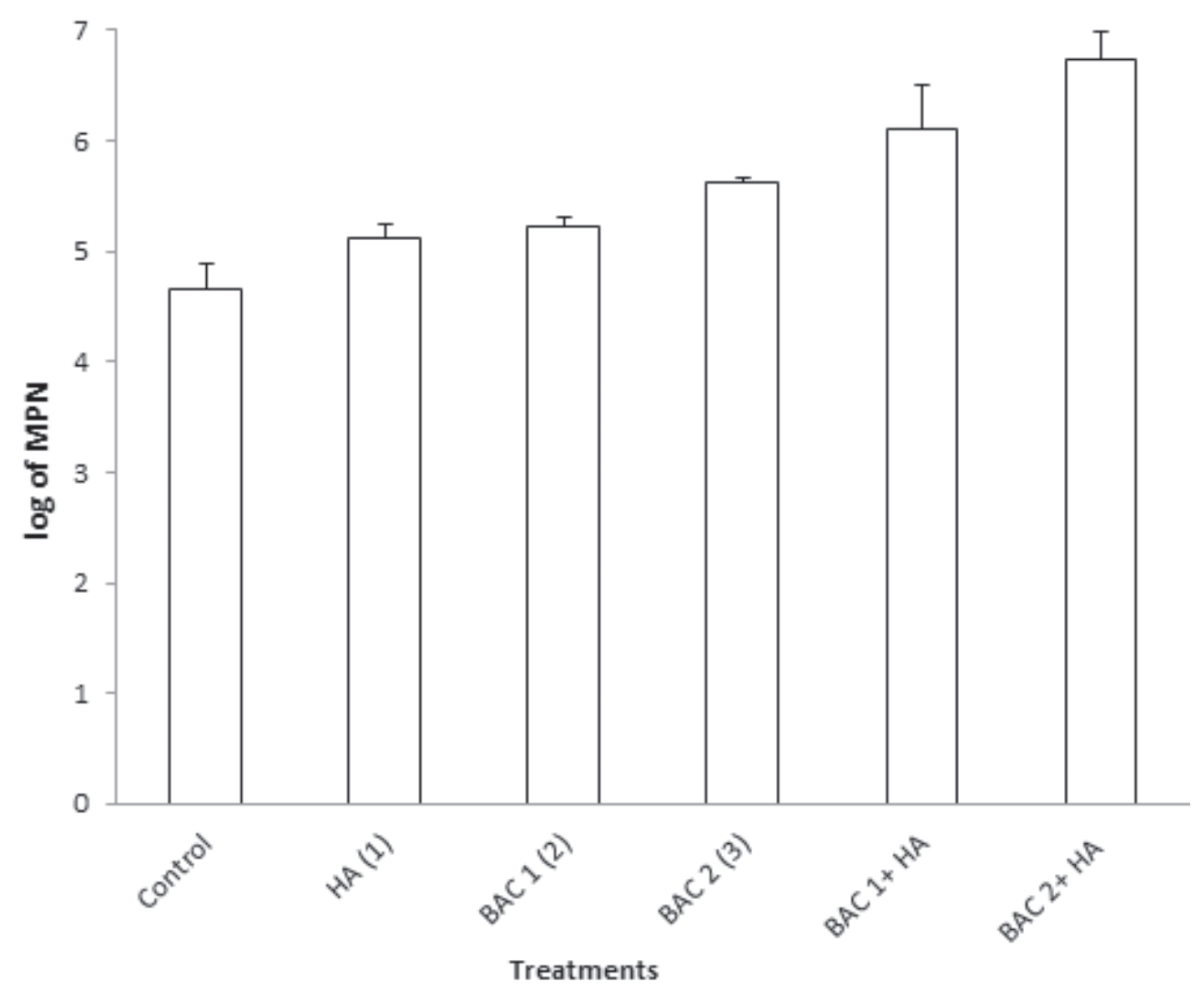

Figure 1: Log of the Most Likely Number (MPN) of bacteria per gram of maize seedlings in response to application of humic acids (HA), inoculation of bacteria (BAC), and use of humic acids and bacteria (HA + BAC).

efficiency. Therefore, bacteria of the Rhizobium cellulosilyticum strain isolated and purified from some plant species, or soil, and inoculated in combination with HA used in maize seed treatment may contribute to greater development of the crop.

On the other hand, similar results in promoting growth with Rhizobium cellulosilyticum strain in combination with HA did not occur for the Burkholderia gladioli strain under the conditions tested. The strain isolated inoculation or application in conjunction with humic acids did not produce significant effects in relation to control in the biometric and nutritional variables performed in the present study (Table 1 and 2). Humic acids increased the population of these strains in the interior of the plants, but in a more sensitive way compared to seeds inoculated with bacteria of Rhizobium cellulosilyticum strain (Figure 1).

Consequently, the results of this work are different from those obtained by Perin et al. (2006) and Estrada de Los Santos et al. (2001), who observed positive effects of growth of maize plants in association with bacteria of the genus Burkholderia. These observations suggest that the promotion of growth promoted by are dependent on the interaction between plant genotype and microorganisms involved in these associations (Matsumura et al., 2015).

Another reason that may explain the different responses in promoting plant growth between different strains can be attributed to the distinct way of infection and colonization of these bacteria in the plants, whereas
Burkholderia can associate to the hosts in a free lifestyle or through internal plant tissues (Compant et al., 2008; Estrada de Los Santos et al., 2001). Rhizobium colonizes only internal plant tissues (Long et al., 2001). The ability to colonize the internal tissues of plants by bacteria can give them an ecological advantage over bacteria that can only colonize epiphytically. The internal tissues of plants provide a more uniform and protected environment for microorganisms than surface conditions where they are exposed to extreme environmental conditions such as temperature, osmotic potential, ultraviolet radiation and microbial competition (Cocking, 2003).

Accordingly, the results obtained in this study show that the initial maize performance with PGPB inoculation applied in combination with HA is different among different strains used in the experiment. The results also demonstrate that PGPB inoculation of the strain Rhizobium cellulosilyticum combined with bioactive fractions of the organic matter in the form of humic acids, can improve maize productivity, besides being an important alternative for the reduction of production costs, through the reduction of fertilizer demand by the crop.

\section{CONCLUSION}

The inoculation of Rhizobium cellulosilyticum bacteria applied together with humic acids isolated from bovine manure in seed treatment increases the initial performance of maize, consequently its productive potential. 


\section{REFERENCES}

Ahemad M \& Kibret M (2014) Mechanisms and applications of plant growth promoting rhizobacteria: Current perspective. Journal of King Saud University - Science, 26:01-20.

Almeida ML, Samgoi L, Nava IC, Galio J, Trentin OS \& Rampazzo C (2003) Crescimento inicial do milho e sua relação com o rendimento de grãos. Ciência Rural, 33:189-194.

Alves GV, Videira SS, Urquiaga S \& Reis VM (2014) Differential plant growth promotion and nitrogen fixation in two genotypes of maize by several Herbaspirillum inoculants. Plant and Soil, 386:5036-5051.

Baldotto MA \& Baldotto LEB (2016) Initial performance of corn in response to treatment of seeds with humic acids isolated from bokashi. Revista Ceres, 63:62-67.

Baldotto MA, Rocha JE, Andrade FDP, Del Giúdice MP \& Baldotto LEB (2016) Plant stimulant humic acid extracted of organic waste recycled by composting combined with liming and fertilization. Semina Ciências Agrárias, 37:3955-3964.

Baldotto LEB, Baldotto MA, Canellas LP, Smith RB \& Olivares FL (2010) Growth promotion of pineapple 'Vitória' by humic acids and Burkholderia spp. during acclimatization. Revista Brasileira de Ciência do Solo, 34:1593-1600.

Baldotto MA, Muniz RC, Baldotto LEB \& Dobbss LB (2011) Root growth of Arabidopsis thaliana treated with humic acids isolated from typical soils of Rio de Janeiro state, Brazil. Revista Ceres, 58:504-511.

Canellas LP \& Olivares FL (2014) Physiological responses to humic substances as plant growth promoter. Chemical and Biological Technologies in Agriculture, 1:01-11.

Canellas LP, Balmori DM, Médici LO, Aguiar NO, Campostrini E, Rosa RC, Façanha AR \& Olivares FLA (2012) Combination of humic substances and Herbaspirillum seropedicae inoculation enhances the growth of maize (Zea mays L.). Plant and soil, 366:119-132.

Conceição PM, Vieira HD, Canellas LP, Marques Júnior RB \& Olivares FL (2008) Corn seed coating with humic acids and endophytic diazotrophic bacteria. Pesquisa Agropecuária Brasileira, 43:545-548.

Cocking EC (2003) Endophytic colonization of plant roots by nitrogen-fixing bacteria. Plant and Soil, 252:169-175.

Compant S, Nowak J, Coenye T, Clement C \& Barka EA (2008) Diversity and occurrence of Burkholderia spp. in the natural environment. FEMS Microbiol Reviews, 32:607-626.

Döbereiner J, Baldani VLD \& Baldani JI (1995) Como isolar e identificar bactérias diazotróficas de plantas não-leguminosas. Brasília, Embrapa-SPI. 60p.

Embrapa - Empresa Brasileira de Pesquisa Agropecuária (2001) Tratamento e manejo de dejetos de bovinos. Juiz de Fora, Embrapa. 2p. (Instrução técnica, 52).

Estrada-De Los Santos P, Bustilios-Cristales R \& Caballero-Mellado J (2001) Burkholderia, a genus rich in plant-associated nitrogen fixers with wide environmental and geographic distribution. Applied and Environmental Microbiology, 67:2790-2798.

García-Fraile P, Carro L, Robledo M, Ramírez-Bahena MH, Flores-Félix JD, Fernández MT, Mateos PF, Rivas R, Igua MJ, Martínez-Molina E, Peix A \& Velázquez E (2012) Rhizobium promotes non-legumes growth and quality in several production steps: towards a biofertilization of edible raw vegetables healthy for humans. PLoS One, 7:01-07.

Günes A, Turan M, Güllüce M \& Sahin F (2014) Nutritional content analysis of plant growth-promoting rhizobacteria species. European Journal of Soil Biology, 60:88-97.
Hungria M, Campo RJ, Souza EME \& Pedrosa FO (2010) Inoculation with selected strains of Azospirillum brasilense and A. lipoferum improves yields of maize and wheat in Brazil. Plant and Soil, 331:413-425.

Idris A, Labuschagne N \& Korsten L (2009) Efficacy of rhizobacteria for growth promotion in sorghum under greenhouse conditions and selected modes of action studies. Journal of Agricultural Science, 147:17-30.

Long SR (2001) Genes and Signals in the Rhizobium-Legume Symbiosis. Plant Physiology, 125:69-72.

Majeed A, Abbasi MK, Hameed S, Imran A \& Rahim N (2015) Isolation and characterization of plant growth-promoting rhizobacteria from wheat rhizosphere and their effect on plant growth promotion. Frontiers in Microbiology, 6:01-10.

Marques Junior RB, Canellas LP, Silva LG \& Olivares FL (2008) Promoção de enraizamento de microtoletes de cana-de-açúcar pelo uso conjunto de substâncias húmicas e bactérias diazotróficas endofíticas. Revista Brasileira de Ciência do Solo, 32:11211128 .

Masson-Boivin C, Giraud E, Perret X \& Batut J (2009) Establishing nitrogen-fixing symbiosis with legumes: how many Rhizobium recipes? Trends in Microbiology, 17:458-466.

Matsumura EE, Secco VA, Moreira RS, Santos OJP, Hungria M \& Oliveira ALM (2015) Composition and activity of endophytic bacterial communities in field-grown maize plants inoculated with Azospirillum brasilense. Annals of Microbiology, 1:01-14.

Melo RO, Baldotto MA \& Baldotto LEB (2015) Corn initial performance in response to humic acids from bovine manure and poultry litter. Semina Ciências Agrárias, 36:1863-1874.

Montañez A, Abreu C, Gill PR, Hardarson G \& Sicardi M (2009) Biological nitrogen fixation in maize (Zea mays L.) by ${ }^{15} \mathrm{~N}$ isotope dilution and identification of associated culturable diazotrophs. Biology and Fertility of Soils, 45:253-263.

Olivares FL, Aguiar NO, Rosa RCC \& Canellas LP (2015) Substrate biofortification in combination with foliar sprays of plant growth promoting bacteria and humic substances boosts production of organic tomatoes. Scientia Horticulturae, 183:100-108.

Pedrosa FO, Monteiro RA, Wassem R, Cruz LM, Ayub RA, Colauto NB, Fernandez MA, Fungaro MH, Grisard EC, Hungria M, Madeira HM, Nodari RO, Osaku CA, PetzlErler ML, Terenzi H, Vieira LG, Steffens MB, Weiss VA, Pereira LF, Almeida MI, Alves LR, Marin A, Araujo LM, Balsanelli E, Baura VA, Chubatsu LS, Faoro H, Favetti A, Friedermann G, Glienke C, Karp S, Kava-Cordeiro V, Raittz RT, Ramos HJ, Ribeiro EM, Rigo LU, Rocha SN, Schwab S, Silva AG, Souza EM, Tadra-Sfeir MZ, Torres RA, Dabul AN, Soares MA, Gasques LS, Gimenes CC, Valle JS, Ciferri RR, Correa LC, Murace NK, Pamphile JA, Patussi EV, Prioli AJ, Prioli SM, Rocha CL, Arantes OM, Furlaneto MC, Godoy LP, Oliveira CE, Satori D, Vilas-Boas LA, Watanabe MA, Dambros BP, Guerra MP, Mathioni SM, Santos KL, Steindel M, Vernal J, Barcellos FG, Campo RJ, Chueire LM, Nicolás MF, Pereira-Ferrari L, Silva JL, Gioppo NM, Margarido VP, Menck-Soares MA, Pinto FG, Simão RC, Takahashi EK, Yates MG \& Souza EM (2011) Genome of Herbaspirillum seropedicae Strain SmR1, a Specialized Diazotrophic Endophyte of Tropical Grasses. Plos Genetics, 7:01-10.

Perin L, Martínez-Aguilar L, Paredes-Valdez G, Baldani JI, Estrada-De Los Santos P, Reis VM \& Caballero-Mellado J (2006) Burkholderia silvatlantica sp. nov., a diazotrophic bacterium associated with sugar cane and maize. International Journal of Systematic and Evolutionary Microbiology, 56:1931-1937.

Rev. Ceres, Viçosa, v. 65, n.3, p. 271-277, mai/jun, 2018 
Poonguzhali S, Madhaiyan M \& Sa T (2008) Isolation and identification of phosphate solubilizing bacteria from Chinese cabbage and their effect on growth and phosphorus utilization of plants. Journal of Microbiology and Biotechnology, 18:773777

Quaggiotti S, Ruperti B, Pizzeghello D, Francioso O, Tugnoli V \& Nardi S (2004) Effect of low molecular size humic substances on nitrate uptake and expression of genes involved in nitrate transport in maize (Zea mays L.). Journal of Experimental Botany, 55:803-813

Qureshi MA, Shahzad H, Imran Z, Mushtaq M, Akhtar N, Ali MA \& Mujeeb F (2013) Potential of Rhizobium species to enhance growth and fodder yield of maize in the presence and absence of 1-tryptophan. The Journal of Animal \& Plant Sciences, 23:14481454.

Ribeiro AC, Guimarães PTG \& Alvarez V VH (1999) Recomendação para o uso de corretivos e fertilizantes em Minas Gerais: $5^{\text {a }}$ Aproximação. Comissão de Fertilidade do Solo do Estado de Minas Gerais, Viçosa, UFV. 322p.
Rodrigues Neto J, Malavolta Jr. VA \& Victor O (1986) Meio simples para o isolamento e cultivo de Xanthomonas campestres pv. citri Tipo B. Suma Phytopathologica, 12:01-16.

Silva AC, Canellas LP, Olivares FL, Dobbss LB, Aguiar NO, Frade DOR, Rezende CE \& Peres LEP (2011) Promoção do crescimento radicular de plântulas de tomateiro por substâncias húmicas isoladas de turfeiras. Revista Brasileira de Ciência do Solo, 35:1609-1617.

Trevisan S, Pizzeghello D, Ruperti B, Francioso O, Sassi A, Palme K, Quaggiotti S \& Nardi S (2010) Humic substances induce lateral root formation and expression. of the early auxinresponsive IAA19 gene and DR5 synthetic element in Arabidopsis. Plant Biology, 12:604- 614. 